\title{
Salinity in the Colorado River in the Grand Valley, Western Colorado, 1994-95
}

- Salinity in the Colorado River is highly dependent on streamflow. In general, high streamflow dilutes salinity, and low streamflow increases salinity.

- Expected high salinity during periods of low streamflow in late summer might partially be offset by reservoir releases in the Upper Colorado River Basin upstream from the Grand Valley.

- Salinity during the irrigation season did not exceed the 700-850 milligrams per liter threshold in the Colorado River near the points of diversion for Grand Valley irrigators.

- Irrigation return flows from the Grand Valley increase salinity in the Colorado River.

\section{Introduction}

Salinity, or the dissolved-solids concentration, is the measure of salts such as sodium chloride, calcium bicarbonate, and calcium sulfate that are dissolved in water. About one-half of the salinity in the Colorado River Basin is from natural sources (U.S. Department of the Interior, 1995), such as thermal springs in the Glenwood-Dotsero area, located about 90 miles upstream from Grand Junction (fig. 1). Effects of human activities, such as irrigation, reservoir evaporation, and transbasin diversions, have increased the levels of salinity in the Colorado River. High salinity can affect industrial and municipal water users by causing increased watertreatment costs, increased deterioration of plumbing and appliances, increased soap needs, and undesirable taste of drinking water.
High salinity also can cause lower crop yields by reducing water and nutrient uptake by plants and can increase agricultural production costs because of higher leaching and drainage requirements. Agricultural losses might occur when salinity reaches about 700-850 milligrams per liter (U.S Department of the Interior, 1994).

The Colorado River is the major source of irrigation water to the Grand Valley (fig. 1) and also is one source of water for the Clifton Water District, which supplies domestic water to part of the eastern Grand Valley. During spring and early summer in 1994, the Colorado River in the Grand Valley had lower than average streamflow. There was concern by water users about the effect of this low streamflow on salinity in the river. In 1994, the U.S. Geological Survey (USGS), in cooperation with the Colorado River Water Conservation

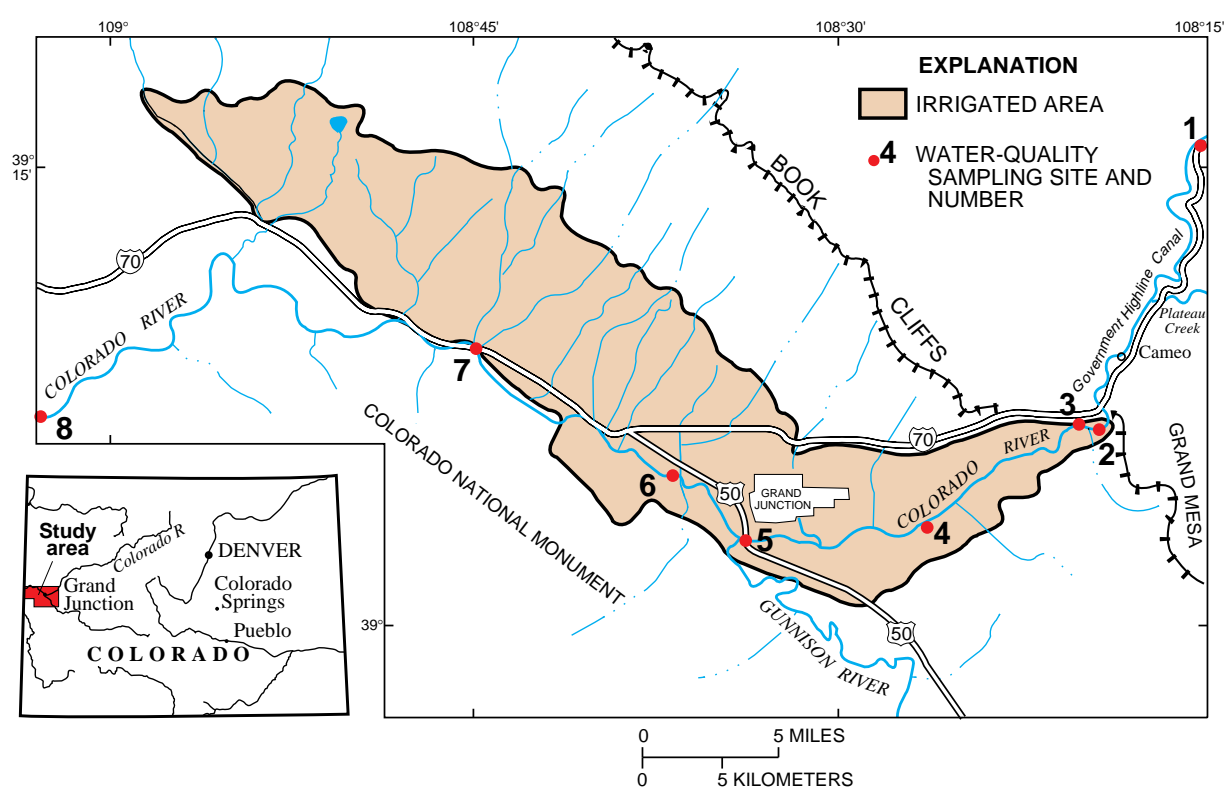

Figure 1. Irrigated area in the Grand Valley and locations of sampling sites for the 1994-95 salinity study of the Colorado River.

District, began a study to evaluate salinity in the Colorado River. This fact sheet describes results of that study. The specific objectives of the fact sheet are to (1) compare salinity in the Colorado River among different locations from Cameo to the Colorado-Utah State line, (2) assess variations in salinity for different times of the year, and (3) describe the relation between streamflow and salinity in the river.

\section{Sampling Sites and Data Collection}

Eight sites on the Colorado River were selected for water-quality sampling. Locations of sampling sites are shown in figure 1 . Site identification and location descriptions are listed in table 1. Samples were collected at two frequencies. Weekly samples were collected at sites 1 through 5 from July 1994 through the first week of November 1994 (table 1) for determination of salinity. Streamflow was measured at the time of sample collection. Monthly samples were collected at all eight sites from July 1994 through April 1995. Monthly samples were analyzed for salinity and for concentrations of major ions such as calcium, magnesium, potassium, sodium, chloride, sulfate, and bicarbonate (expressed as alkalinity). Because of heavy snowpack, there was the potential for high streamflow in the Colorado River ring runoff in 1995. Therefore, monthly sampling was continued through September 1995 at all sites except sites 2 and 4. High streamflow during summer 1995 provided a notable contrast to the low flows of 1994. For example, at the gaging station at site 1 (Colorado River near Cameo), average streamflow for July 1995 was about seven times greater than average streamflow for July 1994 (fig. 2). All waterquality and streamflow data collected for this study are published in USGS annual data reports for Colorado (Ugland and others, 1995; Crowfoot and others, 1996). 
Table 1. Sampling sites and sampling frequency, Colorado River, 1994-95

[Weekly salinity samples collected July 1994-November 1994; monthly salinity samples collected July 1994September 1995]

\begin{tabular}{|c|c|c|c|c|}
\hline \multirow{2}{*}{$\begin{array}{c}\text { Site } \\
\text { number } \\
\text { (fig. 1) }\end{array}$} & \multirow{2}{*}{$\begin{array}{c}\text { USGS } \\
\text { station } \\
\text { number }\end{array}$} & \multirow{2}{*}{ Site name } & \multicolumn{2}{|c|}{$\begin{array}{l}\text { Sampling } \\
\text { frequency }\end{array}$} \\
\hline & & & Weekly & Monthly \\
\hline 1 & 09095500 & Colorado River near Cameo & $\mathrm{X}$ & $\mathrm{X}$ \\
\hline 2 & 390622108205400 & Colorado River at Palisade & $\mathrm{X}$ & $X^{(1)}$ \\
\hline 3 & 09106150 & $\begin{array}{l}\text { Colorado River below the Grand Valley } \\
\text { Canal diversion, near Palisade }\end{array}$ & $\mathrm{X}$ & $\mathrm{X}$ \\
\hline 4 & 390318108273200 & Colorado River at 32 Road, near Clifton & $\mathrm{X}$ & $\mathrm{X}^{(1)}$ \\
\hline 5 & 09106500 & Colorado River at Grand Junction & $\mathrm{X}$ & $\mathrm{X}$ \\
\hline 6 & 390521108373300 & $\begin{array}{l}\text { Colorado River at Redlands Parkway, near } \\
\text { Grand Junction }\end{array}$ & -- & $\mathrm{X}$ \\
\hline 7 & 09153000 & Colorado River at Fruita & -- & $\mathrm{X}$ \\
\hline 8 & 09163500 & $\begin{array}{l}\text { Colorado River near the Colorado-Utah State } \\
\text { line }\end{array}$ & -- & $\mathrm{X}$ \\
\hline
\end{tabular}

${ }^{1}$ Sampling only through April 1995.

\section{Monthly Variations in Salinity and Relation to Streamflow}

Monthly water samples were collected at eight sites (table 1) and were analyzed for salinity. Because monthly samples were collected at six of the eight sites after April 1995 , the following analysis is based on only those six sites $(1,3,5,6,7$, and 8). Monthly salinity data are shown in figure 3 .

Streamflow had a pronounced effect on salinity in the Colorado River in 1994 and 1995. In 1995, the runoff season was late, and high streamflow was prolonged well into the summer (fig. 3). Streamflow in May 1995 at site 1 was only 61 percent of the long-term average (1934-94), but streamflows for June through September were much greater than long-term averages (fig. 2). For example, streamflow in July 1995 was 293 percent of the average July streamflow for 1934-94. At site 8 , the streamflow for July was 395 percent of the average July streamflow for 1951-94. The high streamflow in the basin caused a large decrease in salinity at all sites (fig. 3) when compared to 1994 . The samples having largest differences in salinity were collected in July and August; salinity was much lower in 1995 than in 1994 at all six sites. High streamflow in 1995 also caused salinity among sites to be similar until early September, when the effects of runoff were diminishing.

In general, salinity in the Colorado River is inversely related to streamflow (fig. 3). Salinity tends to be higher at low streamflows and lower at high streamflows. However, the effects of streamflow on salinity might depend to some degree on the time of year. Salinity was highest for sites downstream from the Gunnison River (sites 6, 7, and 8) during August-November 1994 (fig. 3), which is the (site 1 in fig. 1). streamflows. The higher salinity in AugustNovember 1994 for sites 6, 7, and 8 probably was caused by increased salt loading to the river from surface and subsurface irrigation return flows during the latter part of the irrigation season. In contrast to sites 6,7 , and 8 , the highest salinity for sites 1 and 3 occurred during December-February when streamflow was at a minimum. Salinity at site 1 would not be affected by irrigation drainage from the Grand Valley, and the effect of irrigation drainage at site 3 was minimal.

\section{Weekly Variations in Salinity and Relation to Streamflow}

Salinity for weekly samples collected at sites $1-5$ are plotted in figure 4 . Generally, there was a gradual increase in salinity at each site from July 1994 to November 1994 as streamflow gradually decreased. Salinity for weekly samples collected in 1994 was similar among sites 1,2, and 3 (fig. 4). Salinity at sites 4 and 5 was consistently higher than at sites 1,2 , and 3 , and salinity at site 5 was consistently higher than at site 4 . The increase in salinity at sites 3,4 , and 5 in a downstream direction probably is a result of surface and subsurface irrigation return flows to the river.

Although differences in weekly salinity between sites 1 and 2 were small, salinity for

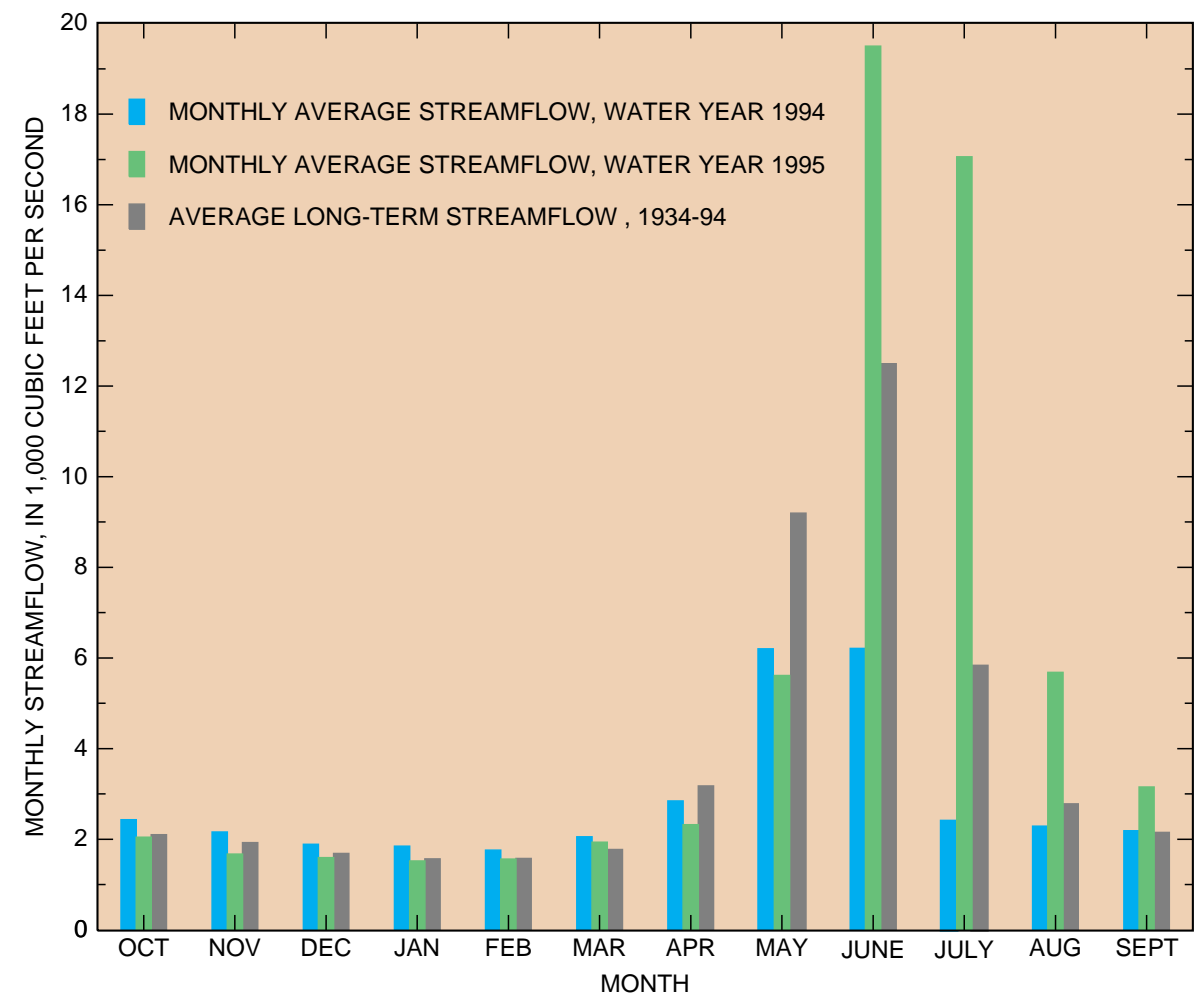

Figure 2. Average monthly streamflow for water years 1994 and 1995 and long-term monthly streamflow for 1934-94 for the Colorado River near Cameo at gaging station 09095500 


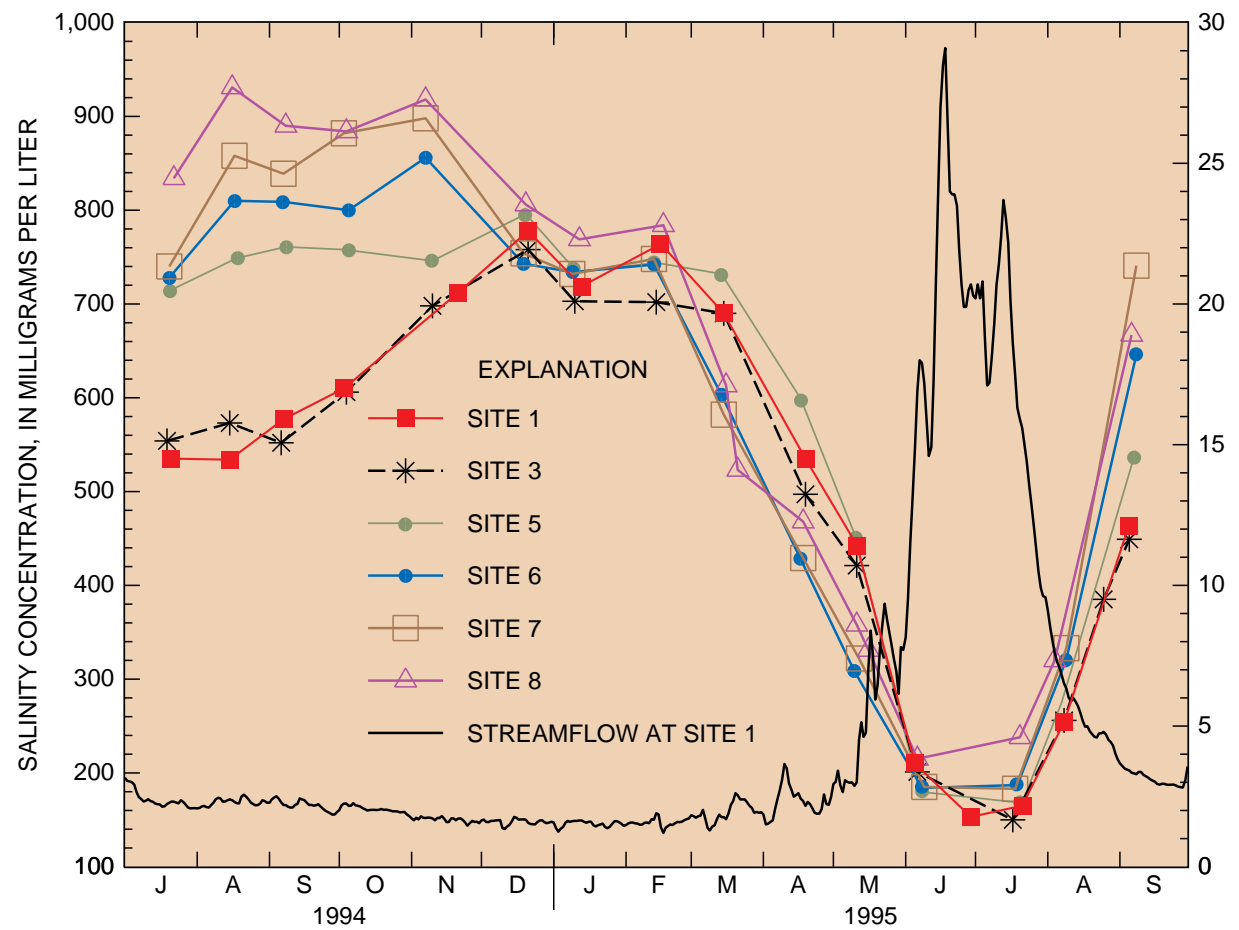

Figure 3. Monthly salinity at six sites on the Colorado River and daily streamflow at site 1, July 1994-September 1995.

15 of the 19 weekly samples was lower at site 2 than at site 1 (fig. 4). The slightly lower salinity at site 2 probably was caused by the diversion of about 1,500 cubic feet per second of water from the Colorado River and by inflow from Plateau Creek (fig. 1) between sites 1 and 2. Salinity in Plateau Creek generally is slightly lower than in the Colorado River, and a small dilution in salinity in this water-depleted reach of the river is evident.

Salinity in weekly samples collected from July through October 1994 at sites 1 and 3 did not exceed the 700-850 milligrams per liter threshold level for agricultural losses. Salinity in samples from those sites should be the same as the salinity in the water diverted from the Colorado River for Grand Valley irrigators. Site 1 is about 6 miles upstream from the diversion point for the Government Highline Canal, and site 3 is immediately downstream from the diversion structure for the Grand Valley Canal. Salinity was about 700 milligrams per liter in the samples collected in November at sites 1 and 3, but that was after the irrigation season had ended.

The possible effects of low natural streamflow in 1994 on salinity in the Colorado River between Cameo and the Gunnison River (sites $1-5$ ) probably were partially offset by reservoir releases. Monthly streamflows at site 1 for May, June, and July were 39 to 70 percent of long-term monthly flows for 1934-94, and weekly salinity for July at site 1 was higher than for most samples collected in
Grand Valley, such as Green Mountain and Ruedi Reservoirs, could have a dilution effect 号 on on salinity in the Colorado River, especially during dry years. Based on data collected by the USGS, water released from those two reservoirs typically has salinity of less than 200 milligrams per liter. Beginning in late July 1994, releases from both reservoirs were increased, and these increased releases augmented flow in the Colorado River. In August 1994, total releases from Green Mountain and Ruedi Reservoirs were about 23 percent of the monthly flow in the Colorado River at site 1 .

\section{Comparison of 1994-95 Data to Historical Data}

The USGS has collected salinity data for many years at site 1 (near Cameo) and at site 8 (near the Colorado-Utah State line) on the Colorado River. Salinity data at both sites in July 1994 were high compared to historical data for 1969-93 because of the below normal streamflow in the river. Salinity at sites 1 and 8 for the remainder of 1994 were not unusual when compared to the historical data. The high and prolonged snowmelt runoff of 1995 caused low salinity in the Colorado River from June to August. Salinity for site 8 during June, July, and August 1995 (fig. 3) was lower than the salinity in samples collected those months during 1969-93.

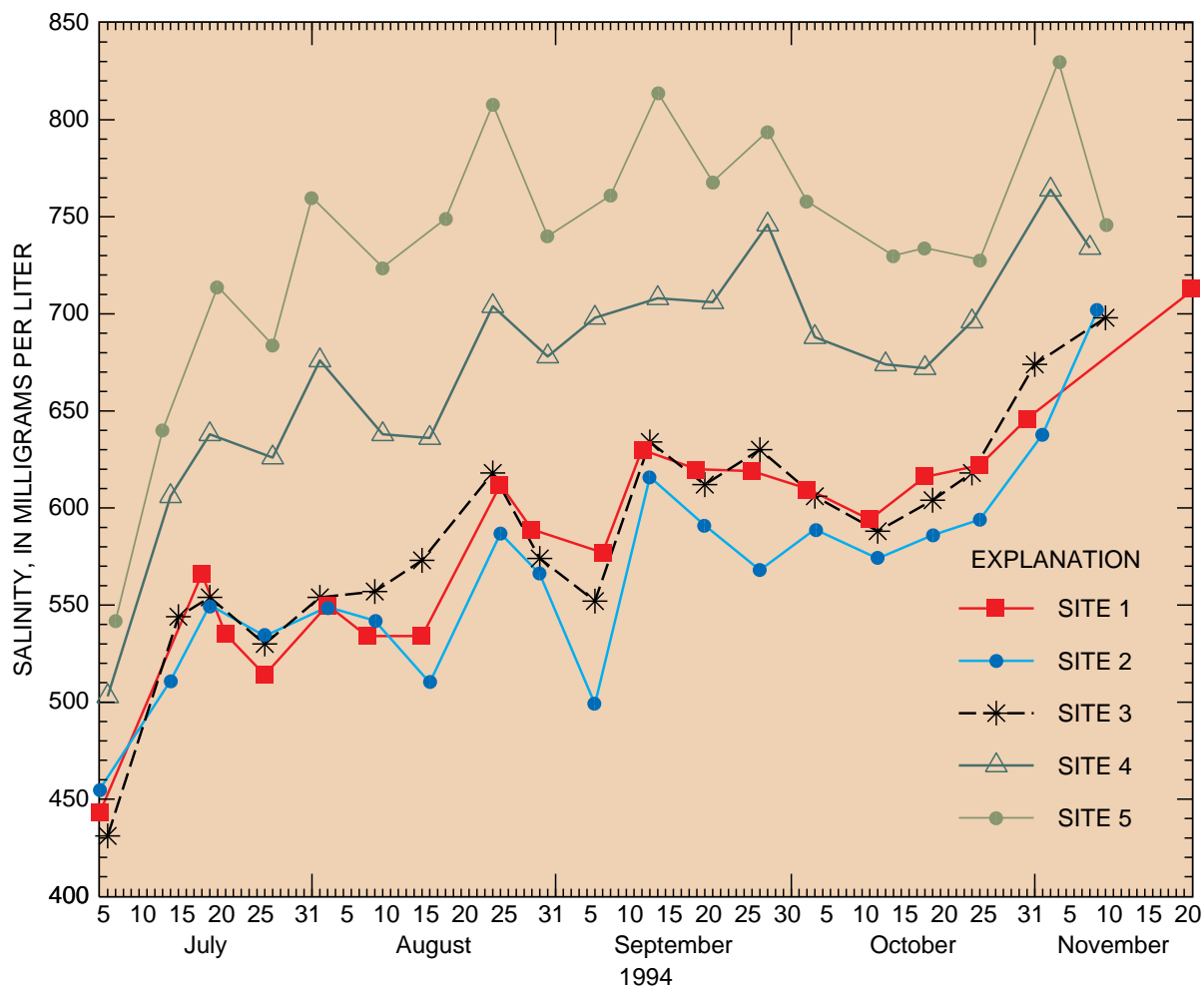

Figure 4. Weekly salinity at sites 1 through 5, July-November 1994. 
Table 2. Mean concentrations of selected major ions and salinity for six sites on the Colorado River, July 1994-September 1995

[Concentrations in milligrams per liter (parts per million)]

\begin{tabular}{cccccccccc}
\hline $\begin{array}{c}\text { Site } \\
\text { number } \\
\text { (fig. 1) }\end{array}$ & Calcium & $\begin{array}{c}\text { Magne- } \\
\text { sium }\end{array}$ & $\begin{array}{c}\text { Potas- } \\
\text { sium }\end{array}$ & Sodium & Chloride & Sulfate & Alkalinity Salinity \\
\hline 1 & 62.4 & 14.6 & 3.2 & 99.3 & 134 & 115 & 134 & 517 \\
3 & 61.3 & 15.1 & 3.2 & 97.0 & 127 & 114 & 140 & 511 \\
5 & 72.8 & 19.5 & 3.3 & 101 & 130 & 158 & 144 & 580 \\
6 & 81.3 & 24.1 & 3.1 & 72.9 & 66.9 & 224 & 140 & 567 \\
7 & 83.6 & 25.3 & 3.2 & 74.3 & 66.8 & 238 & 142 & 587 \\
8 & 87.8 & 26.4 & 3.1 & 78.3 & 71.2 & 252 & 142 & 617 \\
\hline
\end{tabular}

\section{Major-Ion Concentrations}

The monthly samples collected at the eight sites were analyzed for concentrations of major ions (table 2). The most notable feature of the major-ion data listed in table 2 is the differences in ion concentrations in the Colorado River upstream and downstream from the confluence with the Gunnison River (immediately downstream from site 5, fig. 1 ). The chloride and sodium concentrations upstream from the Gunnison River (sites 1, 3, and 5) are considerably higher than downstream from the Gunnison River inflow (sites 6, 7, and 8), and sulfate concentrations are considerably higher downstream from the Gunnison River. The reason for those differences is that chloride and sodium concentrations are lower and sulfate concentrations are higher in the Gunnison River than in the Colorado River upstream from site 5. Therefore, chloride and sodium concentrations are decreased and sulfate concentrations are increased in the Colorado River by inflow from the Gunnison River. Also of note is the increase in some ion concentrations between sites 3 and 5, which reflects the effects of irrigation return flows from the eastern Grand Valley, and between sites 6, 7, and 8 , which reflects the effects of irrigation return flows into the Colorado River from the western part of the Grand Valley.

\section{CONCLUSIONS}

Salinity in the Colorado River in 1994-95 was dependent to varying degrees on streamflow. The less than average runoff in 1994 probably caused unusually high salinity in the Colorado River in July 1994. However, salinity in the Colorado River for August through November 1994 was not unusual when compared to historical data that have been collected at the Cameo and State line gaging stations. Reservoir releases in the Colorado River Basin upstream from the Grand Valley augmented river flows with dilute water and partially offset the effects of low natural streamflows on salinity. The high and prolonged runoff in 1995 seemed to have affected salinity in the Colorado River more noticeably than the low-flow period of 1994. Salinity in July and August 1995 was much lower than in July and August 1994 at six sampling sites on the Colorado River from Cameo to the Colorado-Utah State line.

Salinity during July-October 1994 near the diversion points on the Colorado River for the Government Highline Canal and Grand Valley Canal did not exceed a threshold level at which crop productivity may be adversely affected. Salinity increased in the Colorado River from Palisade (site 2) to the Gunnison River (site 5) and from the Redlands Parkway (site 6, downstream from the Gunnison River inflow) to the Colorado-Utah State line (site 8) because of salt loading from surface and subsurface irrigation return flows. During 1994-95, the highest salinity in the Colorado River between the Redlands Parkway and the State line occurred during August-November of 1994, which probably coincides with the maximum salt loading to the river from irrigation drainwater and return flows.

\section{REFERENCES CITED}

Crowfoot, R.M., Ugland, R.C., Maura, W.S., Jenkins, R.A., and O’Neill, G.B., 1996, Water resources data, Colorado, water year 1995-v. 2, Colorado River Basin: U.S. Geological Survey Water-Data Report CO-95-2, 471 p.

Ugland, R.C., Maura, W.S., Wilson, E.A., and O’Neill, G.B., 1995, Water resources data, Colorado, water year 1994-v. 2, Colorado River Basin: U.S. Geological Survey Water-Data Report CO-94-2, $412 \mathrm{p}$.

U.S. Department of the Interior, 1994, Salinity update: Denver, Bureau of Reclamation, Colorado River Salinity Program Coordinator, $17 \mathrm{p}$.

-1995, Quality of water-Colorado River Basin: Salt Lake City, Utah, Bureau of Reclamation, Upper Colorado Region Progress Report 17, 96 p. plus appendix.

—David L. Butler and Paul von Guerard, Water Resources Division, Grand Junction, Colorado.

- The authors acknowledge the datacollection efforts for this study by Troy R. Taylor and Darrin A. Miller of the USGS.

\section{For more information about this study, write to:}

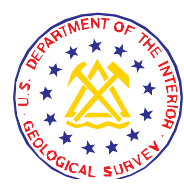

Subdistrict Chief

U.S. Geological Survey

Water Resources Division

Aspinall Federal Building

402 Rood Avenue, Room 230

Grand Junction, CO 81501

email: pbvongue@cronos.cr.usgs.gov

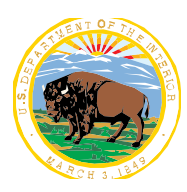

